\title{
Sterilization process by sheet electron beam irradiation for medical glass.
}

\section{電子線照射による医療用ガラスの殺菌処理}

\author{
Akihiro KASASHIMA, Nobuhiro IWATAKA, Junichi KAWANO, \\ Naoshige HONDA and Yoshitake NISHI \\ Department of Materials Science, Tokai University, 1117, Kitakaname, Hiratsuka, Kanagawa, 259-12 JAPAN. \\ TEL : 81-463-58-1211 (EX. 4206)，FAX : 81-463-58-1812
}

\begin{abstract}
Akira TONEGAWA
Department of Physics, Tokai University, 1117, Kitakaname, Hiratsuka, Kanagawa, 259-12, JAPAN.

TEL : 81-463-58-1211 (EX. 3684), FAX : 81-463-58-1812

( Received 8, November 1996 Accepted 13, January 1997)
\end{abstract}

Sterilization process by sheet electron beam irradiation is investigated on a medical glass. Number of colony of E. coli on the surface of the medical glass was reduced by SEBI. SEBI is effective for the sterilization of medical glass.

Key wards : Electron beam irradiation, Medical glass, Sterilization.

\section{I . INTRODUCTION}

現在、光学系を含む医療機器が、診断や治療に 盛んに用いられるようになってきている。1 これ らの装置を医療現場で使用する場合、殺菌処理が 必要となる。この殺菌処理には、高圧蒸気や、高 エネルギーの放射線を用いる方法等がある。 ${ }^{2}$ 方、光学系医療機器のレンズやガラスは、量ると 適切な診断や治療が困難になるため、墨り止め処 理が必要である。この墨り止めの 1 つの方法とし て、放射線の一種である低エネルギーの電子線を ガラスに照射する方法があり、電子線照射により ガラス表面が量らなくなるという報告がある。 そこで本研究では、医療用ガラスに低エネルギー の電子線を照射し、その照射線量が殺菌効果に及 ぼす影響について検討を行った。

\section{EXPERIMENTAL}

試料は、（株）シバタ製医療用歯科ガラスを用 いた。Table 1 にガラスの組成を示す。電子線照射 は、（株）岩崎電気製 ELECTROCURTAIN PROCESSOR ( CB175/15/180L ) を用いて行 つた。 ${ }^{2}$ 電子線の照射条件を Table 2 に示す。な お、電子線の照射量は式（1）を用いて求めた。

$$
\begin{array}{ll}
D=k \times l / S & (1) \\
D: \text { 照射量 } & k: \text { 定数 } \\
I: \text { ビーム電流 } & S: \text { コンベア速度 }
\end{array}
$$

TABLE 1. Composition of medical glass.

\begin{tabular}{|c|c|c|c|c|c|}
\hline $\mathrm{SiO}_{2}$ & $\mathrm{Al}_{2} \mathrm{O}_{3}$ & $\mathrm{Fe}_{2} \mathrm{O}_{3}$ & $\mathrm{CaO}$ & $\mathrm{MgO}$ & $\mathrm{RaO}$ \\
\hline $\begin{array}{l}70 \sim 73 \\
(\mathrm{wt} \%\end{array}$ & $1.0 \sim 1.8$ & $0.08 \sim 0.14$ & $7 \sim 12$ & $1.0 \sim 4.5$ & $13 \sim 15$ \\
\hline
\end{tabular}

TABLE 2. Irradiation condition.

\begin{tabular}{|c|c|}
\hline Acceleration potential & $170 \mathrm{kV}$ \\
\hline Irradiating current & $4 \mathrm{~mA}$ \\
\hline Conveyer speed. & $0.09 \mathrm{~m} / \mathrm{s}$ \\
\hline Atmosphere & $\begin{array}{c}\text { Nitrogen with } \\
\text { atmospher ic pressure }\end{array}$ \\
\hline 0xygen concentration & Less than $400 \mathrm{ppm}$ \\
\hline
\end{tabular}

殺菌効果の指標菌として、比較的手に入りやす い大腸菌を用いた。1 $\mathrm{ml} の$ 蒸留水に大腸菌を 1 エーゼ懸濁し、その内の $1 \mathrm{ml}$ を試料であるガラ ス上 $3.14 \mathrm{~cm}^{2}$ の面積に塗布した。このガラスに 電子線照射処理を行った。その後、試料を $100 \mathrm{ml}$ の蒸留水にいれ擋拌した。この溶液中の $0.1 \mathrm{ml}$ を $100 \mathrm{~mm}$ ディッシュ中の寒天培地上に塗布した。こ こで培地には、他の菌の繁殖を防ぐ（株）日本製 薬製デスオキシコレート寒天を用いた。大腸菌は 培地上で、 $37^{\circ} \mathrm{C}, 20 \mathrm{~h}$ 培養しコロニーを形成させ た。なお、他の菌の混入を防ぐため、使用する器 具に滅菌処理を施した。 
III. RESULTS \& DISCUSSION

Figure 1 は、デスオキシコレート寒天培地上の 大腸菌コロニーの写真である。（a）は末照射を 示し、（b），(c）はそれぞれ $16 \mathrm{Mrad} 、 32 \mathrm{Mrad}$ 照射した時を示している。これより明らかに大腸

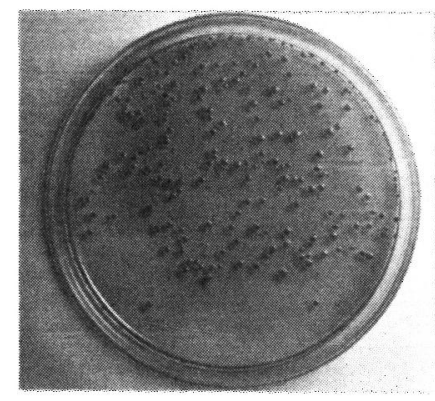

(a) 0 Mrad

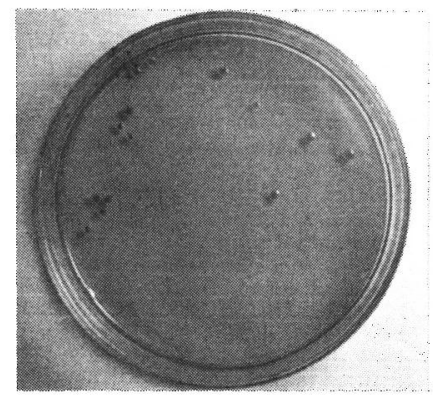

(b) $16 \mathrm{Mrad}$

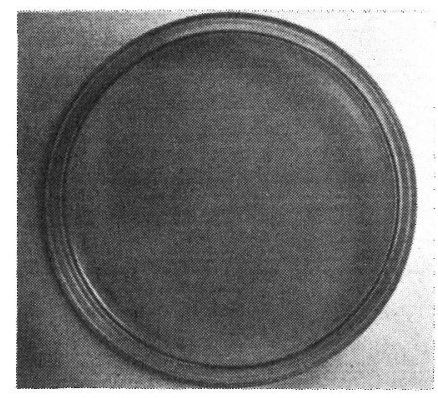

(c) 32 Mrad

FIG. 1. Photographs of colonies of E. coli.
(a) 0 Mrad
(b) 16 Mrad
(c) $32 \mathrm{Mrad}$

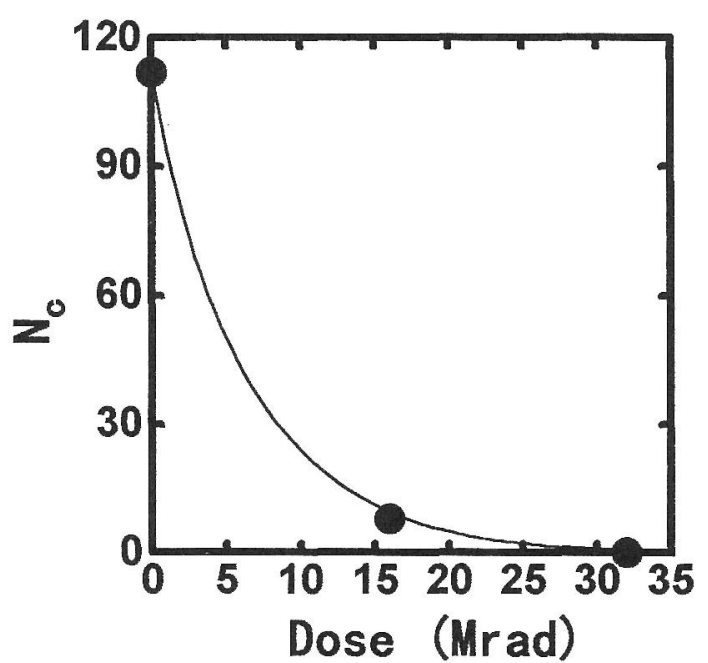

FIG. 2. Change in number of colonies of E. coli against dose and integrated time of SEBI.

菌コロニ一数 $\left(\mathrm{N}_{\mathrm{c}}\right)$ が減少していることが分かっ た。Figure 2 に、Dose 量及び照射時間に対する $\mathrm{N}_{\mathrm{c}}$ の変化を示している。なお、Dose 量及び、照 射時間 $\left(t_{i}\right)$ は1回の照射量の積算で計算した。こ れより、Dose 量の增加にともない $\mathrm{N}_{\mathrm{c}}$ は減少して いるのが分かった。また、32 Mrad 以上では $N_{0}$ が0になることが分かった。ところで電子線照射 は、細胞内の電離作用を引き起こすことで細胞に 損傷を与える可能性と、細胞内の高分子の結合の 一部を破壊する可能性がある。このため、電子線 照射によって大腸菌が殺菌されたと考えられる。

\section{CONCLUSION}

電子線照射は、ガラス表面上に存在する大腸菌 の殺菌処理に有効であることが分かった。

\footnotetext{
REFERENCES

${ }^{1}$ Y. Kusuda, Ryousyoukensakiki, 1\&2, P. 394 (1970)

${ }^{2}$ H. Itou, Ikigaku, 60, 10 (1990)

${ }^{3}$ Y. Nishi, K. Fujita, Journal of Advanced Science, 8, 1\&2, P. 99 (1996)
} 